\title{
BUYERS' LIABILITY FOR PRICE DISCRIMINATIONS UNDER ROBINSON-PATMAN*
}

EITHER buyers or sellers may run afoul of the Robinson-Patman Act's prohibition against price discrimination. ${ }^{1}$ To establish a prima facie case of price discrimination against a vendor, the FTC need only show that one customer received a lower price than another, ${ }^{2}$ resulting in possible injury to competition. ${ }^{3}$ The seller then may defend by proving either that his offending price was set in good faith to meet a competitor's lower price, ${ }^{4}$ or that the price differential was justified by cost savings. ${ }^{5}$ But the FTC has insisted that the

*Automatic Canteen Co. of America v. FTC, 346 U.S. 61 (1953).

1. The Act deals separately with buyers, 49 STAT. 1527 (1936), 15 U.S.C. $\$ 13(f)$ (1946), and sellers, 49 STAT. 1526 (1936), 15 U.S.C. $\$ 13(a)$ (1946). Under these subsections, the FTC has proceeded against approximately twelve times as many sellers as buyers. Rowe, Price Discrimination, Competition, and Confusion: Another Look at Robinson-Patman, 60 YALE L.J. 929, 941 n.72 (1951). The primary purpose of the Act was to curb large buyers. See 80 Cong. Rec. 6287, 8109-11 (1936); Patman, Tul: Robinson-Pataian Act c. 1 (1938).

2. FTC v. Morton Salt Co., 334 U.S. 37, 44-5 (1948) ; Chicago Sugar Co. v. Amcrican Refining Co., 176 F.2d 1, 7 (7th Cir. 1949), cert. devied, 338 U.S. 948 (1950) ; A. J. Goodman \& Son v. United Lacquer Mfg. Corp., 81 F. Supp. 890, 892 (D. Mass. 1949).

3. Corn Products Refining Co. v. FTC, 324 U.S. 726, 742 (1945) ; FTC v. Morton Salt Co., 334 U.S. 37, 46 (1948) ; American Can Co. v. Russellville Canning Co., 191 F.2d 38, 54 (8th Cir. 1951) (freight equalization which "conceivably might substantially lessen competition" held violation).

The other elements of the FTC case against a seller are indicated by the statutory language at 49 STAT. 1526 (1936), 15 U.S.C. $\$ 13$ (a) (1946) :

"Sec. 2(a) That it shall be unlawful for any person engaged in commerce, in the course of such commerce. . ., to discriminate in price between different purchasers of commodities of like grade and quality where either or any of the purchases involved ... are in commerce, where such commodities are sold for use, consumption or resale . . . and where the effect of such discrimination may be substantially to lessen competition or tend to create a monopoly. . . , or to injure, destroy, or prevent competition with any person who either grants or knowingly receives the benefit of such discrimination, or with the customers of either of them."

4. 49 STAT. 1526 (1936), 15 U.S.C. § 13(b) (1946) :

"(b) ... Provided, however That nothing herein contained shall prevent a seller rebutting the prima facie case ... by showing that his lower price ... was made in good faith to meet an equally low price of a competitor. ..."

This proviso is an absolute defense. Standard Oil Co. v. FTC, 340 U.S. 231 (1951).

5. 49 STAT. 1526 (1936), 15 U.S.C. \$13(a) (1946) :

"Sec. 2(a) ... Provided, That nothing herein contained shall prevent differentials which make only due allowance for differences in the cost of manufacture, sale, or delivery resulting from the differing methods or quantities in which such commodities are to such purchasers sold or delivered."

Although another proviso in the subsection allows differentials if justified by changed market conditions, this defense is rarely used. See, e.g., Moore v. Mend Service Co., 190 
cost-justification defense reach almost impossible standards of precision. ${ }^{0}$ Approximate cost allocations are unsatisfactory; generally only a full field study will be accepted. ${ }^{7}$ The FTC has also required buyers to assume the rigorous burden of proving that their receipt of a lower price was justified by the seller's lower costs. ${ }^{8}$ However, the statutory language provides that buyers violate the Act only if they "knowingly" induce or receive "prohibited" price discrimination. ${ }^{9}$ Purchasers therefore argued that this shifted the burden of proof and that a price differential was not a "prohibited" price discrimination until the Commission proved it to be unjustified. ${ }^{10}$ And buyers further contended that the FTC must satisfy the "knowingly" language by showing that the purchaser knew his price was unjustified.11

The recent case of Automatic Canton Co. of Anerica $\%$. FTC ${ }^{12}$ was the first proceeding against a buyer to reach the Supreme Court. ${ }^{13}$ The Com-

F.2d 540 (10th Cir. 1951), cort. donicd, 342 U.S. 902 (1952) (boycott nist a sufieient change in market conditions); Frederick W. Huber, Inc. v. Pillstury Flour Mills Co., 30 F. Supp. 108 (S.D.N.Y. 1939) (changed marketability of fluur a defense).

6. For representative cases and criticism of FTC demands, see Sawyer, Aecoumtis:g and Statistical Proof in Prico Discrimination Cases, 36 Iowa L. Rev. 244 (1951); Nute, Proof of Cost Differentials Under the Robinson-Pafman Act, 65 Hanv. L. Rev. 1011 (1952).

7. Only two sellers have ever successfully established a cost saving defence before the FTC. Bird \& Son, Inc., 25 F.T.C. 548 (1937) ; Minneapolis-Honeywell Regulator Co., 44 F.T.C. 351 (1948), rev'd on other grounds, 191 F.2d 786 (7th Cir. 1951), cert. dismissed as antinnely, 344 U.S. 206 (1952). For a statement of the FTC pasition, see casc Studies in Distribution Cost Accounting for Manufaturing and Wholesaliny, H.R. Doc. No. 287, 77th Cong., 1st Sess. (1941) ; Fuchs, The Requirement of Eractuess is the Justification of Price and Sertice Differintials Under the Rolinson-Palman Act, 30 Texas L. Rev. 1 (1951); Warmack, Cost Accounting Problcns Under the Robunson-Patnan Act in CCH Robinson-Patnan Act Syamosium 105 (1947).

8. See E. J. Brach \& Sons, 39 F.T.C. 535, 547 (1944); Automatic Canteen Co. of America, 45 F.T.C. S61, 896 (1950). See Forkner, The Signifizance of Scction $2(f)$ in CCH Robinson-Patalan Act Sramosiuas 66, 78 (1948).

9. 49 STAT. 1527 (1936), 15 U.S.C. \$13(f) (1946) :

"(f) That it shall be unlawful for any person engaged in commerce, in the course of such commerce, knowingly to induce or receive a diserimination in price which is prohibited by this section."

10. See Brief for Petitioner, pp. 27-9, Automatic Canteen Co. of America v. FTC, 346 U.S. 61 (1953); Brief for FTC, p. 19, Automatic Canteen Co. of America v. FTC, 194 F.2d 433 (7th Cir. 1952) (summarizing the Amicus Carriae argument of the Atlas Supply Co.) ; Howrey, The Bayer and $A$ Prina Facic Case in CCH Ronnso::-Panen:i Act Syarposiuxs 87, SS-91 (1948).

11. Ibid.

12. 346 U.S. 61 (1953).

13. The FTC has brought eighteen cases against buyers under $2(f)$ sinee the passage of the Act, of which only Automatic Canteen Co. of America, 46 F.T.C. 861 (1950), has been reviewed by the courts. Of these, twelve have been decided, all against the buyer, and cease and desist orders issued: Pittsburgh Plate Glass Co., 25 F.T.C. 1228 (1937); Golf Ball Manufacturers' Ass'n, 26 F.T.C. $\$ 24$ (1938) ; MIiami Wholesale Drug Corp., 28 F.T.C. 485 (1939); American Oil Co. and General Finance, Inc., 29 F.T.C. 857 (1939); 
pany, a purchaser of candy for resale through automatic machines, solicited and received lower than list prices from eighty of its suppliers. ${ }^{14}$ The FTC considered a prima facie case established by a showing that the buyer knew it was receiving lower than list prices. ${ }^{15}$ But the Company insisted that the Commission prove knowing acceptance of an unjustified price.10 The FTC refused to introduce evidence indicating a lack of cost justification, and issued a cease and desist order. ${ }^{17}$ The Seventh Circuit affirmed. ${ }^{18}$ The Supreme Court, in a six to three decision, held the FTC's showing insufficient. ${ }^{10} \mathrm{Mr}$. Justice Frankfurter, for the majority, ruled that the Commission must present some evidence indicating that the price was unjustified and also that the buyer knew of this unjustifiability. ${ }^{20}$ The court reasoned on a "balance of convenience" theory that the FTC, with its broad power to investigate and subpoena seller's cost data, could obtain this information more easily than the buyer. ${ }^{21}$ Furthermore, the majority feared that making acceptance of lower than list prices a prima facie violation of the Act would unduly restrict vigorous bargaining by buyers. ${ }^{22}$ While Automatic Canteen clearly told the Commission to show more, it did not specify how much more evidence was required.

A. S. Aloe Co., 34 F.T.C. 363 (1941) ; Atlantic City Wholesale Drug Co., 38 F.T.C. 631 (1944) ; E. J. Brach \& Sons, 39 F.T.C. 535 (1944); Associated Merchandising Corp. 40 F.T.C. 578 (1945) ; The Curtiss Candy Co. of America, 44 F.T.C. 237 (1947), modificd, 48 F.T.C. 161 (1951) ; National Tea Co., 46 F.T.C. 829 (1950) ; Automatic Canteen Co. of America, 46 F.T.C. 861 (1950), aff'd, 194 F.2d 433 (7th Cir. 1952), r'v'd, 346 U.S. 61 (1953) ; Atlas Supply Co., 48 F.T.C. 53 (1951). Three complaints have been dismissed: The Kroger Co., FTC Dkt. 5991, CCH TRADE Reg. Rep. I11,450 (June 24, 1953) (initial decision adopted by the Commission, Sept. 16, 1953; mimeographed copy in Yale Law Library) ; Crown Zellerbach Corp., FTC Dkt. 5421, CCH TRADE REG. REP. \11,466 (July 8, 1953) ; Safeway Stores, Inc., FTC Dkt. 5990, CCH Trade Reg. Rer. $\mathbb{1} 11,474$ (July 27, 1953). And three complaints are pending: Metropolitan Automotive Wholesalers Cooperative, FTC Dkt. 5720-4, CCH TRADE REG. REP. I 11,501 (complaint issued Dec. 20, 1949) ; Sylvania Electric Products, FTC Dkt. 5728, CCH TRAdE REg. Rep. II 11,501 (complaint issued Dec. 21, 1949) ; Mid-South Distributors, FTC Dkt. 5766-70, CCH TrADE REG. REP. 11,503 (complaint issued May 1, 1950). For a discussion of these cases see Drain, A Buyer's View of the Robinson-Patman Act, 16 J. BAR Ass'N, D.C. 245 (1949).

14. Automatic Canteen Co. of America, 46 F.T.C. 861, 895 (1950).

15. Id. at 896 .

16. For the Company's argument, see note 10 supra.

17. 46 F.T.C. $861,889-91$ (1950).

18. Automatic Canteen Co. of America v. FTC, 194 F.2d 433 (7th Cir. 1952). The Seventh Circuit accepted the FTC's theory analogizing buyers' to sellers' suits. Id. at 438 .

19. The majority indicated that Section 2(b) of the Act, 49 STAr. 1526 (1936), 15 U.S.C. $\S 13$ (b) (1946), which places the burden of showing justification upon the "person charged with a violation," applied only to proceedings against sellers. Automatic Canteen Co. of America v. FTC, 346 U.S. 61, 77-8 (1953). Justices Black, Douglas, and Reed dissented on the ground that 2(b) justified the Commission's stand. Id. at 82-3.

20. Id. at 79 .

21. Id. at 78-9.

22. Id. at 73-4. 
Automatic Canteen did not decide whether the FTC has to negate all the seller's defenses or only cost justification. Some broad language in the opinion says that the Commission must show lack of any justification for the price. ${ }^{23}$ And two recent FTC opinions dismissing complaints against buyers apparently interpret Automatic Cantecn to require that all defenses be negated by the Commission. ${ }^{24}$ However, the Supreme Court confined its decision almost entirely to cost justification. ${ }^{25}$ And the Court pointed out that a buyer might be in a better position than the FTC to know whether a price was set to meet another seller's competition. ${ }^{26}$ On a "balance of convenience," therefore, the Commission should not be required to disprove the good faith meeting of competition defense to make out its case.

Even if Automatic Canteen requires the Commission to refute only the cost defense, the opinion does not decide whether the FTC must introduce a full field survey for this purpose. An FTC hearing examiner has recently interpreted Autonatic Canteen to require such a full-scale showing. ${ }^{27}$ Some reasoning in the Supreme Court's opinion supports such a view.3 But it is uncertain whether the investigatory power of that agency is broad enough to allow so complete a survey of a seller's business. ${ }^{29}$ Nor would joining sellers and their customers in one proceeding help the FTC secure an exact cost study to use against buyers. The Commission cannot require that a seller undertake such an expensive study. ${ }^{30}$ And even if the seller undertalies the complex project to defend against an FTC complaint, the Commission will probably reject it as inadequate. ${ }^{31}$ Thus, requiring the Commission to

23. Id. at 74. "We therefore conclude that a buyer is not liable under $\$ 2(f)$ if the lower prices he induces are ... within one of the seller's defenses. . .."

24. See Safeway Stores, Inc, FTC Dht. 5930, CCH TRape REo. Rep. I11,474 (July 27, 1953) ; The Kroger Co., FTC Dlt. 5991, CCH Trupe Reg. Rep. II 11,450 (June 24, 1953) (initial decision adopted by the Commission, Sept. 16, 1953; mimeographed copy in Yale Law Library).

25. Automatic Canteen Co. of America v. FTC, 346 U.S. 61, 79-S0 (1953).

26. Id. at 79 n.23.

27. See Crown Zellerbach Corp., Zellerbach Paper Co., General Pager Co., FTC Dkt. 5421, CCH TEAde REg. Rep. I 11,466 (July \&, 1953). However, the full Commission has not yet considered this question.

28. The Court discussed the full field study required of sellers, Automatic Canteen Co. of America v. FTC, 346 U.S. 61, 68-9 (1953), and subsequently indicated that the FTC must now disprove cost justification. Id. at 79.

29. Although this issue has never been litigated, such a survey might be held too sweeping and unreasonable. United States v. Morton Salt Co., 333 U.S. 632, 652 (1950). But cf. FTC v. Smith, 34 F.2d 323 (S.D.N.Y. 1929) (FTC has wide subpoenz powers). Even if the FTC has power to make the study, its cost would be prohibitive Sawyer, Accounting and Statistical Proof in Price Discrimumation Cases, 36 Iow L. REv. 244, 253 (1951).

30. Cost justification is an afirmative defense which need not be undertaken by the seller. See, e.g., Monolith Portland Cement Co., 47 F.T.C. 1292, 1298 (1951); Ideal Cement Co., 47 F.T.C. 221, 227 (1950) ; Draper Corp., 43 F.T.C. 480, 486 (1947).

31. See notes 6,7 silpra. 
produce a full field study would for practical purposes end enforcement of the Act against buyers.

Automatic Canteen can reasonably be read to require that the FTC show only approximate lack of cost justification. The majority indicates that the Commission need introduce no cost data when the buyer knew of identical purchases by competitors at substantially higher prices. ${ }^{32}$ Requiring a full field study in such a case would be clearly unnecessary. A full cost study seems equally unnecessary where the buyer's competitors pay a substantially higher price for only slightly different purchases. Of course, if quantities purchased and distribution methods vary considerably, or if the price reduction is moderate, courts will probably insist on a more detailed FTC showing on the cost-justification issue. Varying the FTC's burden with the facts of particular cases conforms with the Supreme Court's policy of giving buyers room to bargain, ${ }^{33}$ while leaving the Commission practical means to attack flagrant abuses of bargaining power. ${ }^{34}$

Permitting the FTC to introduce only approximate cost data is particularly reasonable, since Automatic Canteen apparently requires the Commission to refute the cost defense solely as a component of showing the buyer's probable knowledge of unjustifiability. ${ }^{35}$ Automatic Canteen indicates that the Commission may infer constructive knowledge if a reasonable businessman should know that cost savings would probably not justify a price difference. ${ }^{30}$ The reasonable businessman has available only approximate cost data, gathered from trade experience. ${ }^{37}$ Since Automatic Canteen makes buyer's knowledge the crucial element of the FTC's case, ${ }^{38}$ it seems unnecessary to require a refined survey to refute cost justification. The FTC should have to introduce only the rough cost data of which the buyer would have been aware. ${ }^{30}$

32. Automatic Canteen Co. of America v. FTC, 346 U.S. 61, 80 (1953).

33. Id. at 73-4.

34. Id. at $70,79$.

35. For such an interpretation of the case, see 53 CoL. L. Rev. 1009 (1953).

36. Automatic Canteen Co. of America v. FTC, 346 U.S. 61, 80 (1953). The court indicates that little weight should be given the seller's statements on cost justification. Id. at 80 and n.24. Since there is no other way to prove actual knowledge, "the dissenters' fear that the FTC must prove what lay in a buyer's mind seems insubstantial." 53 CoL. L. Rev. 1009, 1010 (1953).

37. See Brief for FTC, pp. 41-2, Automatic Canteen Co. of America v. FTC, 346 U.S. 61 (1953).

38. Automatic Canteen Co. of America v. FTC, 346 U.S. 61, 76 (1953): "[I]t is that element [of knowledge] about which the controversy here centers and to which we must address ourselves."

39. Treble damage suitors have a cause of action under the Robinson-Patman Act. Midland Oil Co. v. Sinclair Refining Co., 41 F. Supp. 436 (N.D. Ill. 1941). In treble damage actions neither party has easier access to the seller's cost data. Therefore, on Automatic Canteen's "balance of convenience" test, the plaintiff should have to introduce no more than approximate cost data. 
Since Autonatic Canteen probably leaves considerable room for RobinsonPatman enforcement against buyers, ${ }^{10}$ large purchasers may try to plan their transactions to escape the Act. One such plan would rely on the defense that prices may be set in good faith to meet the lower, lawful price of a competitor. ${ }^{41}$ If a buyer informed his supplier of a lower ofter by a competing seller, the supplier might then be able lawfully to reduce his own price to meet competition. ${ }^{2}$ Although a seller probalily cannot meet an unlawiul lower price, ${ }^{43}$ courts have held that a seller's offer, even though not justified by cost savings, does not violate the Robinson-Patman Act. ${ }^{\text {is }}$ However, the offer-price distinction has only been applied in proceedings against sellers.

Such a device may encounter both legal and policy objections. A seller can probably only meet a competitor's price to retain old business, not to secure new business. ${ }^{45}$ And since the Act prohibits buyers from "inducing" unlawful prices, ${ }^{46}$ soliciting an unjustified offer may be prohibited to vendees even though sellers can legally make such offers. Furthermore, a court may rule that the whole transaction lacks good faith."iT Since only the most powerful buyers could use the device, courts may view it as an instance of abusing bargaining power which the Robinson-Patman Act, for all its infelicitous draftsmanship, was designed to curb. ${ }^{\text {ss }}$

40. The FTC is studying the record in the original proceding against the Autumatic Canteen Company to determine what further courses of action are open. Communication to the Yale Law Jourval from Earl W. Kinter, General Counsel for the FTC, dated Nov. 3, 1953, in Yale Law Library.

41. See note 4 supra.

42. See Standard Oil Co. v. FTC, 310 U.S. 231, 249 (1951). But a seller cannit merely accept the buyer's statement; he must diligently check its truth FTC v. Staley Mfg. Co., 324 U.S. 746, 759 (1945).

For instances where this defense might have been used by the Automatic Canteen Company, see Transcript of Record, pp. 95, 241, Automatic Canteen Co. of America v. FTC, 346 U.S. 61 (1953).

43. See Standard Oil Co. v. FTC, 340 U.S. 231, 244 (1951). But see Dean Mill: Co. v. American Processing \& Sales Co., 1950-51 Trade Cases T02,777 (N.D. Ill. 1951); American Cooperative Serum Ass'n v. Anchor Serum Co., 153 F.2d 907, 912 (7th Cir. 1946), cert. denied, 329 U.S. 721 (1946). See Simon, Price Diserimisation to sIect Con:petition, [1950] U. of ILL L. Fosusy 575, $5 \& 8$.

44. See, e.g., Package Closure Corp. v. Sealright Co., CCH Traws REs. Rrs. ? 2212.107 (S.D.N.Y. 1943), revid an other grounds, 141 F.2d 972 (2d Cir. 1944); A. J. Goodman \& Son, Inc. v. United Lacquer Mfg. Corp., 81 F. Supp. 890 (D. Mass. 1949). But cf. American Can Co. v. Bruce's Juices, Inc., 187 F.2d 919, 924 (5th Cir. 1951).

45. Carpel Frosted Foods, Inc, CCH Trade Reg. Rep. $\$ 2213.303$ (FTC order issucd Dec. 13, 1951) ; FTC v. Standard Brands, Inc, 189 F.2d 510, 514-15 (2d Cir. 1951).

46. See note 9 supra.

47. See FTC v. Staley Mfg. Co., 324 U.S. 746, 759 (1945); Standard Oil Co. v. FTC, 340 U.S. 231, 250 (1951). The elements of "good faith" remain obscure. See Rowe, Price Discrimination, Competition, and Confusion: Another Loul: at Relinsens-Patman, 60 YaLE L.J. 929, 965-72 (1951) ; Simon, sujru note 43, at 586-90.

48. See Patalan, The Robinson-Pataian act 3-6, 343-5S (1938). 